\title{
Shuttle Trading: Case Study From The Former Soviet Republic
}

A. Abdukadyrov, Lindenwood University, USA

S. Daly, Lindenwood University, USA

\begin{abstract}
This case explores the experience of Mirlan Suyorov, one of thousands of entrepreneurs who started shuttle trading in Kyrgyzstan after the collapse of the Soviet Union. The goal is to show the effects of globalization in the lives of people in former Soviet republics since the 1990s. This research draws mostly upon primary sources such as personal interviews. Through showing the lives of shuttle traders, this study highlights the importance of international trade organizations in shaping the economy of newly independent countries and emerging markets.
\end{abstract}

Keywords: Shuttle Trading; Made in Labels; Customs Unions; Central Asia; Former Soviet Union

\section{INTRODUCTION}

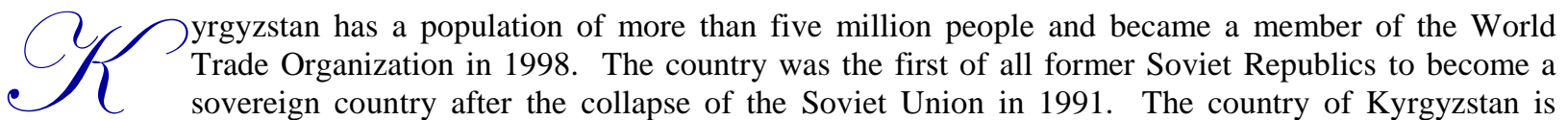
located in the middle of Central Asia, bordering China to the East, Uzbekistan to the West, Tajikistan on the South, and Kazakhstan on the North.

In the 50 years prior to 1991 , Kyrgyzstan was completely dependent on the economy of the Soviet Union. As a result of losing key Soviet inputs in the form of contracts and subsidies, Kyrgyzstan's economy experienced contraction. Major industries of the country suffered sharp reductions in productivity due to disruption in the supply chain of raw materials and fuel. The local government was unable to support and bolster any area of the economy and the machine and textile industries were especially impacted during this time.

Mirlan was a burgeoning entrepreneur in 2002. He graduated from the University of Technology in KyzylKiya in May of that year. Unemployment was high and there was not much left in the city in terms of economic stability or stimulus. The situation over the last decade with the withdrawal of Soviet assistance and then the collapse of the Soviet Union had left his country in a financially unstable and depleted state. Career options were non-existent.

Mirlan devised a plan to purchase cotton fabric produced in the Osh Cotton Mill. Osh is the second largest city in the south of Kyrgyzstan. These cotton products were popular in areas of the former Soviet republics and Mirlan hoped to easily entice sales from Kazakhstan. He chose Kazakhstan due to having relatives that had recently relocated to that country. However, the first problem arose quickly - the cotton mill was in its last stage of life. The shrinking economy had left many machines unused, few repairs made when needed and significantly decreased supply. Many of the area farmers simply grew less cotton due to the low rates of demand for the raw product and very low prices when sold. Many fields were left unplanned or converted to other crops for basic family sustenance.

\footnotetext{
${ }^{1}$ We certify that this is original work, based on real events in a real organization. This case has not been published and is not under review elsewhere. The parties involved have given permission for the use of all information provided.
} 


\section{SHUTTLE TRADE}

Undeterred, primarily due to the lack of options, Mirlan borrowed \$1,000 from a friend in September 2002. He considered himself very fortunate to buy 200 meters of the limited supply of fabric from the cotton mill. He spent $\$ 850$ on this initial purchase. He packed his suitcase with fabric and personally travelled to the Kazakhstan capital city of Astana. He found a buyer willing to purchase the entire lot of 200 meters and sold the fabric for $\$ 1,300$. He spent $\$ 150$ on travel and incidentals and was thus looking at $\$ 300$ in profit upon his return home.

The profit that Mirlan took from this single transaction represented the average annual income for his country at this time. Although the official statistics refer to this as an 'average', it was an average that still left a family with the bare minimum of living standards. Mirlan was young and single, but family obligations and longterm outlooks needed to be considered. He believed that if he could hold off repaying the original loan from a friend, he would be able to increase his business and potentially earn $\$ 1,200$ in one month. He was trying to keep his excitement mixed with reality. He needed to consider roadblocks to his plan.

Mirlan continued the process of purchasing available fabric and shuttling it personally across the border each month until March of 2003. After the collapse of the Soviet Union, the systems of newly independent countries failed to react to the needs of their markets. At that time, new opportunities for people to earn money were created by low restrictions of customs duties in Commonwealth independent states. As a result, many people started travelling to countries, such as China and Turkey, and returning with goods to be sold in local markets. Most of these trades were made with cash; therefore, the transactions were unrecorded. Consequently, the term 'shuttle trader' became very popular due to the nature of creating business and earning money based on the need for an individual to personally shuttle the goods between markets. After six months of successful acquisitions in Osh and sales in Astana, the cotton mill closed its doors.

\section{PHASE TWO}

Astana, in the meantime, was undergoing its own transition. It had traditionally been a small town and was transitioning to the role of capital city for the country of Kazakhstan. Investment in the city was burgeoning and coming from many different areas. The major investor was the government. Kazakhstan is rich in oil and natural resources. The government used the funds from international sales of natural resources to reinvest in and build the country. Businessmen also chose to invest in Astana with the anticipation of its being named the capital city. The economy was growing at a steady and healthy rate. Demand was increasing in many sectors, especially in the area of high quality products of all kinds. Cotton fabric was definitely in demand. Entrepreneurs were readily attracted to the atmosphere and environment of Astana.

Mirlan felt he had a small advantage as an entrepreneur at this juncture in Astana's history since he already had six months of experience in shuttle trading in the city. Mirlan had managed to make and save a net profit of $\$ 8,000$ over his first six months in business. He paid off the debt to his friend and planned to use the remaining profits as capital to start his business again.

\section{THE "MADE IN CHINA" ERA BEGINS}

After becoming a WTO member, China began to flood the Kyrgyzstan's market with inexpensive goods. This created an opportunity for many Kyrgyzstanis to create a personal cushion against the impact of unemployment and inflation. Moreover, an open trade policy created a climate of new entrepreneurism to earn money by reexporting Chinese goods to neighboring countries. Chinese goods coming into Kyrgyzstan could be used in the shuttle trade climate already well established and resold in Russia, Kazakhstan, and Uzbekistan. None of these countries were members of the WTO and, to this day, are still not members. Mirlan quickly found himself one of thousands of shuttle traders.

Mirlan decided to concentrate on cotton fabric in the hopes of capitalizing on existing contacts and knowledge gained from working with the Osh mill. However, the Chinese fabric was of a much lower quality than that provided from Osh. Mirlan still considered this his best trade option and business opportunity. The profit 
margin would be considerably lower due to the lower selling price, and competition was significantly higher. The abundance of both cheap fabric and the large number of entrants in the shuttle trade increased the level of competition.

Mirlan set a goal of ten percent net profit. He had started a family and felt a desire to be very organized and purposeful in his business. For two years, he was able to maintain this net profit goal. He stabilized his business contacts, his demand and supply cycles, and reputation. Two years later (in 2005), he was ready to expand. After careful planning, Mirlan opened a sewing shop in Astana and hired five workers whom he considered excellent and diligent employees. The shop produced finished clothing items for sale to retailers and semi-finished products that were targeted for the Astana market. All fabrics were purchased from Dordoy Bazaar in Kyrgyzstan.

Dordoy Bazaar is the largest shopping central in Central Asia. It is just outside the borders of the Kyrgyzstan capital of Bishkek. The Dordoy Bazaar had a thriving and significant business base going back 20 years. Most goods sold there were imported from China and Turkey. Thailand, Europe and Russia also represented countries of origin for the product base, but to a much smaller percentage. Most products sold at the Dordoy were then re-exported to Kazakhstan, Uzbekistan, and Russia. Shoes, clothing, construction materials, furniture, toys, electric and electronic equipment, and automotive supplies could all be found in this one place. There was no rail access to the Dordoy or the second largest shopping area - the Kara-Suu Bazaar, so shuttle traders were in high demand and thrived on the opportunities presented by these economic centers.

Once the high volume of Chinese goods increased the level of shuttle trade at these markets, charter bus routes were created that served only these traders. Most goods intended for the shuttle trade left the market via cars and trucks. The World Bank estimated that in 2007, 70,000 Kyrgyzstanis were employed as shuttle traders and that these two market bazaars represented 33\% of the country's GDP. By 2009, the percentage of Chinese products in these two bazaars was 75\% and 85\%, respectively (Dordoy and Kara-Suu). The informal trade process made it difficult to compute the total imports from China to Kyrgyzstan, but estimates range from two to ten billion dollars.

Local manufacturers could not compete with the inflow of Chinese goods. However, the textile industry used the situation to its advantage. Kyrgyzstan became the number one manufacturer of clothes for Central Asia. The "Made in Kyrgyzstan" label became commonplace for clothing and was generally considered desirable and of higher quality than the competing textile products.

The downside was that Kyrgyzstan's economy became highly vulnerable and dependent on the supply of Chinese goods. The risks to swings in the available supply chain were real and significant. Additionally, the quality of the products coming out of China were quite variable and did not seem to be subject to control measures that made sense to those evaluating the products once they arrived at the bazaars.

\section{THE GLOBAL CRISIS}

The 2008 global crisis did not leave Kyrgyzstan unaffected. As with many economic crises, political relations with its neighboring countries became strained. Kazakhstan temporarily closed its borders due to clashes between anti-government protesters and security forces. These clashes resulted in the ousting of the president, deep instability and political turmoil. Mirlan was forced to close his shop in Astana. In 2009, he was eventually able to buy Turkish-made children's wear from Dordoy Bazaar and shuttle it to Kazakhstan.

In 2011, the Russian government initiated and formed a customs union with Belarus and Kazakhstan which caused prices for imported goods from any other country to rise within the three-member countries. Officials at the Dordoy Bazaar estimate that product sales and turnover decreased by $70 \%$ once this customs union formed.

\section{TODAY}

Mirlan has a few options available to him. He could make contact directly with Turkish manufacturers and partner with them to distribute clothing in specific areas. The customs union, unreliable transportation methods, and political relations between his country and Turkey are all considerations in this option. He could maintain a minimal business base as is and hope for an alleviation of the customs union. 
Mirlan also has to consider that his country's leaders could join the customs union. However, in order to do this, they would need to leave behind their membership to the World Trade Organization. Another option is to assess the likelihood of Russian and Kazakhstan becoming WTO members and thus disbanding the customs union. Mirlan was trying to put his years of business experience and his education to use by evaluating which option was most likely and how each option would impact him, his business, his family, and former employees. The uncertainty was great and the global crisis was not going away fast. His country had been in the process of absorbing change after change since the disbanding of the Soviet Union and he was determined to remain an entrepreneur. However, he was not sure if the $21^{\text {st }}$ century had a place for shuttle traders.

\section{QUESTIONS}

1. What were roadblocks to consider after the first successful transaction and sale of fabric in Kazakhstan?

2. What other markets could Mirlan have considered? Would they present better business options?

3. Did six months experience give Mirlan a real advantage in Astana? Was he overstating this experience?

4. What are some factors that could affect the supply level and quality of products coming out of China?

5. Evaluate the business model time-frames that Mirlan uses and compare it to the long-term perspective that is available to businessmen in politically and economically stable countries. What impact and to what depth is the lack of ability to plan long-term a factor in building a business beyond the 'start-up' phase?

6. After the customs union, what other options might have been opened for Mirlan other than working with Turkish Manufacturers?

7. Research the customs union in this case. What are its pros and cons? Do you think it was simply a political strategy against the 'west'?

8. Discussion Topics: political risk; business strategy; ethics; the "Made In..." or country-of-origin impact; country analysis.

\section{AUTHOR INFORMATION}

Mr. Azizbek Abdukadyrov is a Graduate Assistant at Lindenwood University in St. Charles, Missouri. Azizbek is from Kyrgyzstan, Central Asia. He has worked and lived in Moscow, Russia and Istanbul, Turkey. Most of his experience is in the field of international finance. E-mail: azizbeka@gmail.com (Corresponding author)

Dr. S. Daly is an Assistant Professor of Business at Lindenwood University in St. Charles, Missouri. Dr. Daly has worked and lived in several Eastern European countries, was awarded an AACSB fellowship, and spent almost a decade in the aerospace industry. E-mail: sdaly@ lindenwood.edu (Corresponding author) 